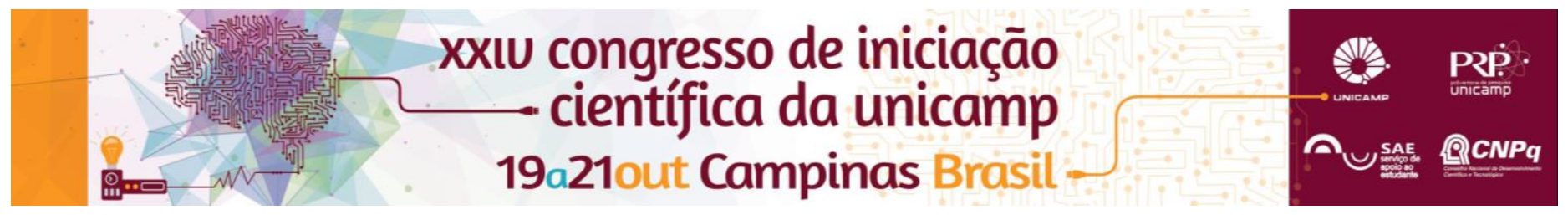

\title{
A linguagem das mulheres na rede social: um estudo dos comentários relacionados ao feminismo e ao machismo em postagens de páginas do Facebook
}

\section{Prof $^{\mathrm{a}} \mathrm{Dr}^{\mathrm{a}}$ Anna Christina Bentes, Isabella Colmanetti Abdalla*}

\begin{abstract}
Resumo
O presente estudo teve como objetivo investigar como as mulheres interagem socialmente em rede social e de que forma, por meio da análise de comentários do Facebook de três páginas selecionadas, elas se empoderam ou (re)elaboram suas imagens enquanto mulheres. Para isso, observou-se o uso de expressões referenciais e recategorizações por parte de mulheres militantes e não militantes, tendo em vista o conceito de feminismo e a questão de se considerar ou não feminista. A pesquisa foi norteada pelo viés da etnografia virtual estabelecido por Hine (2004) ${ }^{1}$, com conceitos linguístico-textuais amparados em $\mathrm{KOCH}(2011)^{3}$ e pela orientação do ciberfeminismo, entendido neste estudo como "uma prática feminista em rede, que tem por intuito, tanto politicamente, quanto esteticamente, a construção de novas ordens e desmontagem de velhos mitos da sociedade através do uso da tecnologia." (MARTíNEZCOLLADO e NAVARRETE apud LEMOS (2009))2. Concluiu-se que houve a (re)elaboração textual-discursiva de identidades das mulheres a partir da análise das expressões referenciais utilizadas nos três dados selecionados, já que os usos dessas expressões empoderaram as mulheres no contexto midiático e reforçaram tanto a luta contra o machismo quanto as reivindicações do feminismo.
\end{abstract}

\section{Palavras-chave:}

Feminismo, Linguística Textual, Estudos de mídia.

\section{Introdução}

As novas mídias digitais colaboraram para construir um cenário de maior mobilização no que se refere ao feminismo e aos discursos relacionados a esse conceito. Analisou-se o uso de expressões referenciais por parte de mulheres militantes e não militantes em postagens e comentários no Facebook, que tinham como finalidade (re)categorizações de si, de suas interlocutoras, do feminismo e da condição da mulher. Sendo assim, este estudo pretendeu evidenciar (i) como novas maneiras de enunciar as problemáticas relacionadas às mulheres podem fazer com que elas (re)elaborem suas imagens; (ii) como esses novos modos de enunciação fazem com que elas construam textualmente, nas redes sociais, seus textos sobre sua própria identidade de forma a empoderar não somente a si mesmas, como também às demais mulheres.

\section{Resultados e Discussão}

Em relação aos dados, foram analisados comentários sobre diferentes postagens de três páginas, a saber: (i) Eta Mídia Machista, (ii) Hoje eu Quero Voltar Sozinha e (iii) Empodere duas Mulheres. De cada página foi selecionada uma postagem para que fosse possível analisar os comentários tanto relativamente à página escolhida quanto ao link compartilhado. No primeiro dado, em uma postagem compartilhada da página do UOL pela Eta Mídia Machista, observou-se que a categorização feita para feminismo por uma usuária nos comentários como "feminista chata" e a expressão referencial "dramas que essa mulherada faz para chamar atenção" não obtiveram total recusa, enquanto que na página Eta Mídia Machista houve total discordância em relação a essas expressões como caracterizadoras do movimento e das mulheres que o seguem. No segundo dado, em um texto da página PorQueNão?, compartilhado pela Hoje eu Quero Voltar Sozinha, notou- se que a escritora, Viviane Noda, não se intitulava feminista mesmo sentindo-se cansada do assédio que sofria. Entretanto, passou a concordar com o significado do termo "feminista" para categorizar a si mesma como tal devido à discussão feita por usuárias, em ambas as páginas, a partir de seu texto. As intervenções feitas por elas mobilizaram categorizações como "a revolta diante do machismo" e "o ato de repudiar esses atos é algo tipo feminista". Por fim, o terceiro dado, constitui-se de uma notícia do portal $G 1$ em que uma mulher tinha sido agredida pelo namorado. Enunciados como "alguma coisa ela fez pra merecer" e "a mulher tem que se sujeitar ao homem" foram alguns dos comentários encontrados no portal. Entretanto, foi possível perceber que o uso de categorizações nos comentários da página Empodere Duas Mulheres, tais como "machismo nosso de cada dia" e "a mulher é livre" fortaleceram uma forte causa feminista: a não culpabilização da vítima.

\section{Conclusões}

Concluiu-se que houve a (re)elaboração textual-discursiva de identidades das mulheres a partir da análise das expressões referenciais e categorizações utilizadas nos três dados selecionados, já que os usos dessas expressões auxiliam no empoderamento das mulheres no contexto midiático e reforçam tanto a luta contra o machismo como as reivindicações do feminismo.

\section{Agradecimentos}

Agradeço ao CNPq pela oportunidade e a Anna Christina Bentes, minha orientadora, por me me ajudar a construir esse projeto.

1 HINE, C. Etnografía Virtual. Barcelona: Editorial UOC, 2004 2 LEMOS, M. G. Ciberfeminismo: novos discursos do feminino em redes eletrônicas. Dissertação de Mestrado. São Paulo: PUC, 2009. ${ }^{3} \mathrm{KOCH}, \mathrm{I}$. G. V. Desvendando os segredos do texto. São Paulo: Cortez, 2011. 